\title{
BNZ-gamma peptide, a potential therapeutic agent in HTLV-1 associated myelopathy
}

\author{
Raya Massoud', Yoshimi Enose-Akahata', Yutaka Tagaya ${ }^{2}$, Nazli Azimi ${ }^{3}$, Steven Jacobson ${ }^{1 *}$ \\ From 16th International Conference on Human Retroviruses: HTLV and Related Viruses \\ Montreal, Canada. 26-30 June 2013
}

The precise mechanism of HAM/TSP pathogenesis remains unclear however many findings suggest that HTLV-1 can activate the infected lymphocytes in the peripheral circulation leading to enhanced migration into the CNS. Once in this compartment, there is preferential expansion of the infected cells and a compartmentalized interaction between virus-specific CD8+ $\mathrm{T}$-cells and virus- infected CD4+ lymphocytes leading to bystander damage of neural tissues. Dysregulation of $\mathrm{T}$ cells activation has been reported in HAM/TSP, particularly dependent on the induction of the stimulatory cytokine loops IL-2/IL-2R $\alpha$, IL-15/IL-15R $\alpha$ and IL-9/IL$9 \mathrm{R} \gamma$ by the virus. All these cytokines share a common chain receptor, the gamma chain $(\gamma \mathrm{C})$, offering a potential therapeutic target. BNZ- $\gamma$ is a 19-mer peptide, that was designed based on the presence of a moderately conserved region shared by all six members of the Gamma cytokine family (IL-2, IL-4, IL-7, IL-9, IL-15 and IL-21) in their D-helix structure. In vitro, we showed that BNZ- $\gamma$ selectively blocks binding and downstream signaling of Il-2, IL-9 and IL-15. In PBMC of HAM/TSP patients, BNZ- $\gamma$ suppressed ex-vivo spontaneous proliferation (SP) in the majority of the tested samples. Additionally a pegylated form of the peptide (N-PEG40) could suppress SP, CD25 expression and STAT5 phosphorylation in the CD8+ T-cells. More importantly, N-PEG40 decreased proliferation of Taxspecific CD8+ cells, a known pathogenic effector cell in HAM/TSP. We are currently studying its effects on functional markers of effector /memory T-cells. These results suggest that manipulation of the inflammatory cytokine loops may be of therapeutic value in the treatment of HAM/TSP.

\footnotetext{
* Correspondence: jacobsons@ninds.nih.gov

1 Viral Immunology Section, Neuroimmunology Branch, National Institutes of Neurological Disorders and Stroke, Bethesda, MD, USA

Full list of author information is available at the end of the article
}

\section{Authors' details}

'Viral Immunology Section, Neuroimmunology Branch, National Institutes of Neurological Disorders and Stroke, Bethesda, MD, USA. ${ }^{2}$ Institute of Human Virology, University of Maryland School of Medicine, Baltimore, MD, USA. ${ }^{3} \mathrm{BIONIZ}, \mathrm{CA}$, USA.

Published: 7 January 2014

\section{doi:10.1186/1742-4690-11-S1-P14}

Cite this article as: Massoud et al:: BNZ-gamma peptide, a potential therapeutic agent in HTLV-1 associated myelopathy. Retrovirology 2014 11(Suppl 1):P14.
Submit your next manuscript to BioMed Central and take full advantage of:

- Convenient online submission

- Thorough peer review

- No space constraints or color figure charges

- Immediate publication on acceptance

- Inclusion in PubMed, CAS, Scopus and Google Scholar

- Research which is freely available for redistribution

Submit your manuscript at www.biomedcentral.com/submit
() Biomed Central 